\title{
Study on the Connection Problems and Countermeasures of the Integration of Ideological and Political Courses in Colleges and Primary and Middle Schools
}

\author{
Hao Zhang Rui Zhang* \\ College of Marxism, Xi'an University of Technology, Xi'an, Shanxi, 710048, China
}

\section{ARTICLE INFO}

Article history

Received: 23 April 2021

Revised: 30 April 2021

Accepted: 15 October 2021

Published Online: 30 October 2021

Keywords:

Undergraduate and specialist education and compulsory education

Ideological and political theories teaching in all courses

Connection

\begin{abstract}
The integration of ideological and political curriculum which exists in colleges and compulsory education is a powerful guarantee for enhancing the effectiveness of the course. Putting theoretical content as well as teaching practice into effect contributes to every improvement and new idea about the curriculum. Facing the new circumstances, new tasks, and new challenges under the social background, it is necessary to reinforce the connection of the integration of the subject in universities and colleges and compulsory education, and take problems as the research direction for the sake of expanding the channels for courses ideological and political construction, and understand the integrated evolution of ideological and political theory courses of undergraduate and specialist education and compulsory education to a higher degree. Grasping the current situation and problems of the theory curriculum in colleges and compulsory education, and exploring the content of the theory in undergraduate and specialist education and compulsory education are of great significance, both in the integrated construction of ideological and political theory courses of undergraduate and specialist education and compulsory education and in making the best of the courses to implement the basic task of fostering people.
\end{abstract}

\section{Introduction}

Ideological and political courses, as a systematic new educational project to cultivate people, make great contributions to lift the connotative progress of the curriculum, which request the organic connection of undergraduate and specialist education and compulsory education in the dimensions of time and space. In March 2019, the President of China pointed out at the teacher's symposium about the theory that taking the overall plan in consideration to elevate the integrated construction of political courses in undergraduate and specialist education and compulsory education as a significant project to accelerate the connotative progress of the curriculum is essential ${ }^{[1]}$. In August 2019, Several Opinions on Deepening the Reform and Innovation of Ideological and Political Theory Courses in Schools in the New Era were issued by the General Office of the CPC Central Committee and the General Office of the State Council, which has clarified that the construction of ideological and political courses in schools in the new era should be planned as a whole so as to accomplish the basic connection and integration of the teaching material system, teaching content, and teacher training of undergraduate and specialist education and compulsory education. It has

*Corresponding Author:

Rui Zhang,

College of Marxism, Xi'an University of Technology, Xi'an, Shanxi, 710048, China;

Email:11394141@qq.com 
further clarified the integrated establishment of ideological and political courses undergraduate and specialist education and compulsory education ${ }^{[2]}$. Thus, for the sake of promoting the overall construction of ideological and political courses in undergraduate and specialist education and compulsory education, it is necessary to break the object that emphasizes form and neglects moral education, to prevent the lack of connection of education goals, content and standards, to eliminate the negative slack of the curriculum in the co-construction and sharing system, to comprehensively enhance the construction of the courses and moral education. Meanwhile, to integrate the resources of the subject in undergraduate and specialist education and compulsory education, to promote the seamless connection of theoretical and practical ideological and political courses, and to cooperate to promote a new layout for the integration of the courses in undergraduate and specialist education and compulsory education.

\section{The Necessity of Connecting Courses Teaching of the Ideological and Political The- ories in Undergraduate and Specialist Edu- cation, and the Moral Education of Primary and Secondary Schools}

It is at the work conference national ideological and political education for undergraduate and specialist education that the top leaders of the Party of the country stressed that the ideological and political theory courses are the key courses in terms of the basic task of strengthening moral education and cultivating people, which run through universities and colleges and primary and middle schools. Various courses must be combined with the curriculum teaching in the accordant orientation and start to exist and develop a synergistic impact. The subjects of ethics and rule of law in primary and secondary schools are basic courses which guide students to establish correct values, while the theories teaching in undergraduate and specialist education is the principal channel and soul curriculum which is responsible for effectively and efficiently carrying out the Party's educational policy, reinforcing moral education and fostering people's fundamental tasks. The system construction of the theory teaching in all courses requests that all the course teaching are supposed to stick to the right political direction, grasp the overall direction of curriculum development and subject moral education construction under the background of promoting the integration of the course in undergraduate and specialist education and compulsory education, clarify the connection and guidance of the theories teaching along with moral education in elementary and secondary schools in the education and teaching system, deepen the reform of school curriculum education, make the curriculum system better than before, explore the intersection of curriculum ideological and political development and moral education development with socialist values guiding, and completely comprehend the coordination as well as resonance of ideological and political elements in the educational function for the sake of establishing a common discourse system which satisfies the demands of contemporary students, promote the innovation of reinforcing moral education and fostering people, realize the requirements of advancing with the times, cultivate newcomers in charge of national rejuvenation ${ }^{[3]}$, and meticulously paint a necessary blueprint in the completely new era in terms of constructing universities curriculum ideology and moral education in elementary and secondary schools.

\section{Problems Existing in the Connection of Ideological, Political, and Moral Education in the Courses of Undergraduate and Specialist Education and Compulsory Education}

\section{There is a phenomenon that ideological and political curriculum in undergraduate and specialist educa- tion and compulsory education attaches great im- portance in form and neglects moral education}

The Party's top leaders made a totally new judgment on the role of the education. At the beginning, they proposed that education was the country's major project and the Party's major project, who put education at an unprecedented height and took cultivating builders and successors of socialism developing in their appreciation of aesthetics and in the matter of their moral, intellectual and fitness level as the main part at the National Education Conference. Among the comprehensive development of labor, "moral education" ranks first, and young students gradually foster their outlook of life in the crucial period of elementary and middle school. It is very significant to receive quality and moral education, however, in the actual elementary and middle school education, moral education is seriously formalized and marginalized. Only carrying out moral education in the courses may easily lead to the "two skins" phenomenon with other curriculum education, which leads to a loose connection between classroom teaching and practical teaching. Ideological and political courses are not carried out through practical activities, but only constant indoctrinization, which makes it difficult for students to get the correct ideas into their minds. Besides, the content of moral education is facing 
a serious "outdated" problem and the content of moral education can't keep up with the trend of young people's thinking, which is too old-fashioned. In the meantime, the construction of moral education is also influenced by society. As economic development develops, such as "money worship", "hedonism" and other wrong thoughts, as well as the development of network technology, primary and middle school students are more likely to be exposed to bad information and moral education is facing more and more challenges. Thus, the integration of the courses can only improve classroom teaching effects through overall planning and reasonable layout.

\section{The content of ideological and political courses in undergraduate and specialist education and compulsory education, is not closely connected}

The curriculum concept separates itself from practice, which lacks compatibility. The ideological and political courses in compulsory education are divided into four parts: mental health, morality, law, and education in national conditions at the junior high school stage. However, influenced by open-book examinations and lower scores, the degree, to which politics courses in junior high schools are valued, is generally not enough. The ideological and political courses in senior high schools are divided into four parts: politics, economy, culture, philosophy, which are compulsory courses. The curriculum evaluation lacks quantitative and unified standards, and their standards are unclear. Due to branches of the college entrance examination and due to the fact that the particularities of physics, chemistry, biology and other subjects are difficult to be related to teaching ideological and political theories, there is a serious polarization in the theories teaching in elementary and secondary schools.

Curriculum evaluation is only based on subject scores. Therefore, the level of the courses of "students majored in science" at universities is generally not as good as "students of liberal arts", which is also the reason why schools have difficulty in enhancing the integrated implementation of ideological and political courses in undergraduate and specialist education and compulsory education. Meanwhile, college teachers in the theory teaching have insufficient understanding of elementary and secondary school textbooks. Besides, their teaching is independent of each other, which lacks cooperation. Furthermore, the evaluation of ideological and political courses in undergraduate and specialist education and compulsory education also has a separate system at the practical level, which separates from each other and which is independent of each other ${ }^{[4]}$. The content of the courses in elementary and secondary schools may be too different from that of the ideological and political courses in compulsory education. What's more, the repetition of the content of the curriculum is redundant and the coherence is not strong. Since the ideological and political curriculum in undergraduate and specialist education has added the legal content that are seldom in the primary and secondary schools' courses, it is relatively difficult for students to accept. The ideological and political courses of colleges and universities are too superficial in terms of legal content, and the pointed education of undergraduate and specialist education and compulsory education overlap, and some of the content is incapable of satisfying students' demands when they enter society from school. Thus, Not only should more attention be paid to the connection in the disciplines at the primary and secondary schools, but university education should also take into account how to continue to implement the theory education. In this way students can not only broaden the horizons but also understand the demands of various subjects and stages and the experience of mutual connection, thereby making it a complete and organically connected curriculum content construction system.

\section{The system of co-construction and sharing of ideological and political resources in undergradu- ate and specialist education and compulsory edu- cation is weak}

The foundation is to co-construct and share the subject's resources in undergraduate and specialist education and compulsory education, while sharing is the goal. Under the background of informationization, the advantages of informatization, digitization and intelligence in the subject system are not obvious. Factors such as regional issues and development level issues always influence the judgment of value identity and emotional morality. First of all, the way teachers of the courses in universities and colleges and primary and middle schools cooperate with each other is relatively simple, which lacks academic research and has their own characteristics. Teachers in colleges, universities, middle schools, and primary schools can only study the teaching of curriculum education corresponding to this stage, so it is difficult to co-build and share an integral and cohesive education system. Secondly, some teachers have deviations in their understanding of the combination of curriculum resources and information technology. If they simply regard information technology as the tool, gradually suffer from passive slackness and laziness in teaching, and have a weak sense of sorting out the knowledge structure and core content of textbooks, it 
will be hard for them to start from the overall situation. And the students will be easy to have a slack mood in the learning process. Thirdly, due to the different personnel who formulate curriculum standards in primary and middle schools, as well as universities, the total planning of curriculum standards in different stages lacks a sense of co-construction and sharing, and the university-related ideological and political curriculum standards have not been unified, which leads to the problem of convergence and which is a prominent problem before educators.

\section{The Connection of Ideological and Political Theories Education in Undergraduate and Specialist Education with Subject Moral Education in Compulsory Education}

The integration of the subjects courses which are in undergraduate and specialist education and compulsory education works as a whole, and the different phases of education are interconnected. The previous stage is the gradual and foundation of the next stage, while developing and improving the previous stage are followed closely. The elementary school phase is the enlightenment moment with regard to students to "seed", the middle school stage is the growth period for students to "grow", and students can mature to "booting" in the university stage. In the common cause of cultivating newcomers of the age, the referred courses of colleges, elementary schools and secondary schools are all "Golden Lessons", which is an inseparable organic part. The "discipline moral education" in elementary and secondary schools and the referred theories teaching in undergraduate and specialist education and compulsory education are a consistent entirety. In allusion to the problems and challenges arising from the theories teaching in the elementary and secondary schools, the reasons and results of the theories teaching in all curriculum should be analyzed in detail so as to fundamentally build an ideological and political system that meets the demands at any time, coordinate the effect of the structure of the theory in the same orientation, draw a well-integrated "concentric circle", and build a new pattern of collaborative teaching of the relevant subject curriculum.

\section{Improve the layout of emphasizing forms and neglecting moral education}

Firstly, schools should adopt different educational methods and teaching methods for students of different grades, position moral education goals scientifically and rationally, firmly grasp the content, methods and ways of moral education, and design the rationale as a whole, and take the integrated constructing of the curriculum on ideological and political teaching of colleges and elementary and middle schools as the guidance, deeply enhance the integration of moral education of "strengthening moral education as well as cultivating people", and build a large pattern of the courses, thereby making moral education penetrate layer by layer and organically connect, and promoting the core values of socialism from mind internally and simultaneity externally. Secondly, as the builders of moral education and the "mainstay" of the construction of the curriculum, college and university teachers must be in possession of a high level of profound and professional knowledge and a richer ideological and political practice and theory, and organically combine the two in the teaching process of profound and professional courses for the purpose of strengthening students' awareness of moral education and stimulate their enthusiasm for the referred education. Finally, in response to the passive impact from society, schools should take the initiative to meet the challenge and launch different ideological and political education for different wrong thoughts. Meanwhile, they are supposed to "concentrate on the concerns of young people" as well as the constantly updated moral education concepts. And they should be good at using the positive aspects of new social thoughts to guide and educate students. Thus, When it comes to teaching and educating people, scientific inquiry, and teacher growth and development, it is very essential to come to know the integrated establishment of ideological and political teachers in universities and colleges and primary and middle schools, coordinate the curriculum setting system, and improve the channels for ideological and political establishment.

\section{Improve the integrated connection of ideological and political courses in undergraduate and specialist education and compulsory education}

Ideological and political courses in colleges, middle schools and primary schools are the key courses for the basic task of providing temporary morality. Educational authorities at all levels should build and improve the relevant systems and mechanisms for the integrated establishment of the courses on the subject in universities and colleges and primary and middle schools, straighten out the relationship, and do a good job of linking up the curriculum standards at different stages in order to make sure that the content of moral education courses in colleges and elementary and middle schools is well connected with the relationship between textbooks at various stages during the teaching process. In accordance with this requirement, teachers of ideological and political curriculum in colleges are supposed to take the initiative 
to study the teaching materials of compulsory education, grasp the overall requirements of the courses, promote the coordination and cooperation of the education on the subject in different stages ${ }^{[5]}$, and go deep into the classrooms of elementary and secondary schools. On account of research, in accordance with the requirement of the courses on the subject in universities and colleges, they are expected to draw up a reasonable teaching plan to avoid too much repetition with primary and secondary schools. Meantime, there is necessity considering what students are truly face who are in the difficult points of the curriculum on the subject in universities and colleges to avoid excessive "jump-thinking" knowledge points. Teachers in compulsory education schools should particularly analyze the different ideological and political levels of "students of liberal arts", formulate different teaching plans in accordance with student groups in different situations, and make relevant adjustments in terms of class time allocation, key reviews, and assignments. In terms of legal knowledge, to prevent the superficiality of the content of the professors, the courses on the subject in colleges should be close to the students' lives, proceed in an orderly way and little by little, impart knowledge from easy to more difficult, and closely combine legal knowledge with ideological and political education. Thus, innovating the ideological and political curriculum system, developing characteristic schoolbased courses, exploring relevant goals, and linking content and standards are a need and a useful attempt to promote the "coordinated operation" of ideological and political courses in universities and colleges and primary and middle schools. Thus, in order to enhance the integration of the education on the subject in universities and colleges and primary and middle schools, there is necessity designing curriculum content in line with the laws of students' cognition and reflect the personalities of various phases. The emphasis of the undergraduate and junior college stage is to carry out theoretical learning, the emphasis of the senior high school stage focuses on the development of learning of common sense, and the emphasis of junior high school stage focuses on the development of learning of common sense, and the emphasis of primary school is to carry out enlightenment learning ${ }^{[6]}$. Only in this way, can students begin to exist and gradually develop a particular shape of a correct view of life, world outlook and standards.

\section{Boost the co-establishment and sharing of curriculum resources relying upon information methods}

As the head and front of the education of universities and colleges and elementary and middle schools, ideological and political theory curriculum is a profound and systematic strategic project before realizing the coconstruction and sharing. The integration of the courses in undergraduate and specialist education and compulsory education should learn from grid thinking. Under the guidance of the construction concept, weaving the courses on the subject of universities and colleges and primary and middle schools into the same education and teaching grid ${ }^{[7]}$ requests efficient communication and exchanges among countries, localities, and schools and educators. For the sake of realizing the co-construction and co-sharing of specific resources, it is necessary to rely on the innovative and integrated development model of electronic equipment, set up a network sharing forum, optimize education and teaching resources, guide students to "buckle the first button" of knowledge ${ }^{[8]}$, explore curriculum integration construction standards, and establish integration awareness, take the initiative to break through the barriers of the academic stage. For the sake of exploring the significant and difficult points of the connection of the courses on the subject in universities and primary and middle schools, it is necessary not only to analyze the changing trends and logical connections of curriculum teaching in many aspects, but also to coordinate the construction of the relevant curriculum resources, promote the integration process of the courses on the subject, and enable resource to develop and realize co-construction and sharing. It is also necessary to broaden the vision of socialist core values, coordinate the educational forces of different regions, explore the imbalance of regional development, expand the digital supplies and resources of the curriculum ranging from the depth of digitization, intelligence, and information, and transform from self-thinking to collaborative thinking, and promote the country, local governments, and collaborative educators at schools to form a new pattern so as to create a good resource co-construction and sharing environment, as well as ideological and political integration of undergraduate and specialist education and compulsory education.

\section{Conclusions}

In a word, to promote the integration of ideological and political courses in universities, primary and secondary schools is the only way for ideological and political disciplines to comply with the development of The Times, and the inevitable requirements for the implementation of moral education. The construction of an integrated connection system of ideological and political courses in primary and secondary schools should not only be rooted in the education and teaching practice of ideological and 
political courses, but also focus on the forefront of reform and innovation of ideological and political courses. It should not only be based on different development tasks in different regions of different students, but also take into account the physical and mental development laws and characteristics of teenagers in the new era. Therefore, it is of great significance to build a system that connects ideological and political courses between primary and secondary schools, promote the cooperation in education and teaching of ideological and political courses between different students, and realize the integration and connection of courses.

\section{Funding}

Educational and Teaching Reform Research Key Project of Xi' an University of Technology - Research and Practice of Course Ideological and Political Teaching Reform Under the Leadership of Party Building (XJY1911); Postgraduate Educational Reform Research Project of Xi'an University of Technology — Correlational and Simultaneous Research and Practice on Graduate Professional Courses and Ideological and Political Theory Courses.

\section{References}

[1] Make Efforts to Build the Ideological and Political Theory Courses in Colleges and Universities into Excellent Courses That Students Truly Love to Benefit from Life-long Unforgettable Life - The Speech of the Minister of Education Yuan Guiren and All the Students in the Training Class of the Backbone Teachers of the Ideological and Political Theory Courses in Colleges and Universities [J]. Leading Journal Of Ideological \& Theoretical Education, 2010(06): 4-6.

[2] Xiao Guiqing. Basic Ideas for the Construction of Ideological and Political Theory Courses in Schools in the New Era [J]. Journal of Jishou University Social Sciences, 2020, 41(02): 34-41.

[3] Xi Jinping: The Governance of China [M]. Beijing: Foreign Languages Publishing House, Xi Jinping, 2020.6 .

[4] Lu Lige, Ye Xuyan, Wang Shijuan, Li Liang, Liu Xiangyu, Wan Meimei, Chen Diming, Sui Murong, Zhang Kangjun, Zi Yanyang. Coordinate and Promote the Integrated Construction of Ideological and Political Courses in Colleges and Universities and Primary and Middle Schools - Learning General Secretary Xi Jinping's Important Speech at the Teacher's Forum on School's Ideological and Political Theory Courses [J]. Journal of Beijing University of Technology (Social Sciences Edition),2020,20(01):9-25.

[5] Ma Baojuan, Zhang Tingting. Integration of Ideological and Political Courses in Colleges and universities and primary and middle schools: Problems and Countermeasures[J]. Ideology and Politics Teaching, 2020(02): 4-8.

[6] Wang Cunxi, Tian Renlai. Discussion on the Integration of Ideological and Political Courses in Colleges and Universities and Primary and Middle Schools [J]. The Party Building and Ideological Education in Schools, 2021(06): 40-42.

[7] Cheng Yong, Zhang Fengchi. Research on the Integrated Construction Strategy of Ideological and Political Courses in Colleges and Universities and Primary and Middle Schools [J]. The Party Building and Ideological Education in Schools, 2020 (08): 3637.

[8] Zhang Hao. Exploration on the Innovative of Ideological and Political Theory Courses Under the Concept of Strengthening Moral Education and Cultivate People [J]. Journal of Taiyuan Urban Vocational College, 2020(07): 125-127. 